\title{
Evaluating the Firm's Readiness for Internationalization: from the Design to the Application of an International Qualification Framework
}

\author{
Jean-Paul David ${ }^{1} \&$ Guillaume Cariou $^{1}$ \\ ${ }^{1}$ Mercadex International, Canada \\ Correspondence: Jean-Paul David, CEO, Mercadex International, Canada. E-mail: jpdavid@mercadex.ca
}

Received: April 10, 2014

Accepted: May 8, 2014

Online Published: June 22, 2014

doi:10.5539/ijbm.v9n7p1

URL: http://dx.doi.org/10.5539/ijbm.v9n7p1

\begin{abstract}
In light of the major changes having marked the evolution of SME global expansion over the past two decades, this article revisits export diagnostic frameworks and advances updated approaches. As the conditions and variables that have characterized the SME's internationalization process have been overhauled, a new framework is required to evaluate their readiness for going global. Supported by research findings and by SMEs' practical experiences abroad, this article lays down an international qualification framework that goes beyond the binary provision "Go or No Go" in that it casts a wider focus upon the new realities facing the SME overseas. Indeed, the international qualification framework proposed specifies the SME's preparedness for internationalization then defines preliminary axes in terms of product-market couples and internationalization modalities.
\end{abstract}

Keywords: SME, internationalization, export, diagnostic

\section{Introduction}

Afirm may decide to expand its activities to foreign markets for various reasons: growth, long-term survival, profitability, economies of scale, supply chain security, business risk diversification, etc. In doing so, it exposes itself to greater challenges and to new risk factors (e.g., foreign exchange, cultural gaps, etc.) that will have to be grasped to better avoid or eventually mitigate them. For beyond the motives and benefits associated with the firm's international expansion, the numerous challenges inherent in such a strategic move can not only compromise its international project, but also strike a blow to its domestic activities. Still, setting out to conquer foreign markets can turn out to be contra-indicated for certain firms not possessing certain assets or specific capacities to face the hurdles associated with this type of project. That is why several "export diagnostic" frameworks have emerged over the past few decades to evaluate the firm's capacities for exporting.

Evaluating the capacities of the firm readying itself for export is recommended not only by researchers but also by most practitioners and international business consultants (Cavusgil \& Nason, 1990). Some suggest identifying a reference market from which the firm's export diagnostic can be carried out (Kumcu \& Gill, 1995).Also, it is interesting to note that from the early days, experts in the field recommended the export diagnostic framework not only for assigning in a binary fashion (Go or No Go) the firm's suitability for exporting, but also to bring into focus its options in terms of distribution channels within the selected markets. In fact, many internationalization models deal with selecting the right country or selecting the right entry mode as part of a two-pronged process (Meier \& Meschi, 2010).

For SMEs, a broader set of international operations beyond exporting needs to be considered. Some research focuses on how alliances between SMEs may facilitate entry into new markets. These arrangements between two or more independent firms can be viewed as a way to share resources, outmatch competitors or limit risks but also as a way to ease access to foreign markets through a set of agreements, e.g., joint ventures, joint research and development or technology exchange agreements (BarNir \& Smith, 2002). Entering foreign markets through an alliance or a partner's network is seen at first as largely a reactive or opportunistic strategy leading to a geographically close market, but then to a broader and more structured international implantation over the years (Coviello \& Munro, 1997). These international networks between SMEs also appear to rely on a single person or a very small group of individuals able to develop and maintain contacts in various countries. Stabilizing these networks requires patience and constant negotiation between partners (Hara \& Kanai, 1994). 
But the problem is that in the wake of significant trends impacting international business (David, 2007) since the fall of the Berlin Wall (economic integration, growth in information technologies, convergence in consumption patterns, shortening of the product life cycle etc.), a gap has widened between the reality of international business and its conditions for success on the one hand, and the evaluation criteria used by export diagnostic frameworks on the other. In light of the growing number of SMEs that adopt internationalization strategies other than export (e.g., licensing, franchising, joint ventures, consortia, foreign direct investment etc.) and of SMEs that even in their startup phase broaden their activities onto the international scene (Oviatt \& McDougall, 1994), this article proposes revisiting existing diagnostic frameworks and their avenues for improvement. Lastly, a new framework is proposed to assess the abilities of an SME that wants to increase its chances of success in its internationalization process.

\section{Methodology}

The issue raised above was studied using three research components. A literature review, the first component, was conducted to review the main literature on existing export diagnostic frameworks. In light of the observations of this first phase, the Delphi method (Note 1) component was arranged, to which a panel of 15 experts in international business (authors, researchers, recognized practitioners often cited in the literature) participated. Two successive iterations of exchanges over the literature were carried out. The experts hailed from nine countries: Australia, Canada, France, Germany, Mexico, Sweden, Switzerland, the United States and the United Kingdom. The outcome led to the development of a framework to qualify firms seeking to internationalize themselves. The third research component, carried out over a period of 4 years, involved validating the practical application of the framework while accompanying 54 Canadian SMEs into international markets. Revenue for the SMEs of the group varied between $\$ 0$ (startups) and $\$ 55 \mathrm{M}$ (CAD) while the overall average was $\$ 7.2 \mathrm{M}$. A little less than two thirds of the SMEs (63\%) were already doing business globally, $37 \%$ weren't. The 54 SMEs studied originated from just over a dozen different industries (construction, chemical manufacturing, wood product manufacturing, plastic and rubber manufacturing, transportation equipment, professional and technical services, software publishing etc.).

\section{Research Findings}

Although studies on SME export are growing in number (Luong, Leo, \& Philippe, 2010), the scientific literature dealing with SME preparedness for internationalization or export diagnostic frameworks is far from prolific. Further, Knight and Kim (2009) observe that despite the increased presence or participation of SMEs globally, little research has been conducted on the intangible resources they should be investing in to operate abroad. Inspired by the Uppsala theory, one of the first books to deal with these issues was written by Wiedersheim-Paul, Welch and Olson (1975) and develops the fundamentals of a first construct for evaluating the firm's pre-export phase. Four components are analyzed: 1) exposure of the firm's management to export related stimuli, 2) commitment of the firm's management (psychological and attitudinal), 3) the firm's resources (tangible and intangible) and 4) lateral rigidity (the firm's management perception regarding the challenges and risks associated to export).

However, Tan, Brewer and Liesch (2010) highlight that the literature is not unanimous on evaluating the firm's internationalization capacities. These researchers have also recently dealt with the development of an export preparedness index, again, based on the conceptual framework of Wiedersheim-Paul, Welch and Olson (1975), the traditional approach to the internationalization process. Through a factor analysis conducted with 290 Australian firms, Tan, Bewer and Liesch's model generated 8 key factors (triggers and inhibitors) for initiating the internationalization process.

For their part, Knight and Kim (2009) dealt with the specific competencies that SMEs must possess to facilitate success in their overseas efforts. The authors were able to develop a model relating SME performance in foreign markets to competencies in international business, arguing that these competencies consist of three constructs: the SME's international orientation, its international business abilities and its capacity for innovation in an international context. Though the financial resources of the SME active abroad are often modest, those SMEs who distinguish themselves tend to leverage their more fundamental resources, often the intangible ones which are consequently harder to obtain (management vision, willingness to be involved internationally, know-how etc.).

In addition, an abundance of practical diagnostic frameworks emerged starting in the mid-1980s, most of which resulted essentially from empirical or even intuitive approaches, and designed at the behest of public bodies engaged in promoting exports. The vast majority of the frameworks were developed for SMEs operating in the secondary sector of the economy, intending to export their products to predetermined markets. The economic 
development agencies were looking for a way to evaluate SME suitability for initiating the export process and offering those presenting a promising profile the appropriate support (consulting, subsidies, financing etc.). Before long, the string of free trade agreements signed starting in the early 1990s combined with promotional campaigns aiming to boost SME export activity led to the widespread use of such diagnostic frameworks. Not wishing to be outdone, private export consulting firms joined in, integrating these frameworks to their practice as they gradually became criteria or conditions for the support of export initiatives (in the eyes of public agencies).

However, by the beginning of the new millennium, the classic diagnostic framework had already begun to be cast aside. According to the Delphipanel, two factors explain this disaffection. The first relates to the simplistic nature of such frameworks in that they only reflect the responses provided by the firm, accompanied by a score and a conclusion of the type "Go or No Go".Further, so limited was the value added of the auditor that the joke was "they look at their client's watch to tell them the time".Self-diagnostic export frameworks then began to appear from which SME managers could perform their own export audit. Yet, the lack of perspective or objectivity associated with their inexperience and lack of export knowledge made it difficult for the self-diagnosis to be valid, valuable and useful all at the same time.

The second factor in justifying revisiting the export diagnostic framework is related to how the internationalization process of SMEs has evolved. Over the past 15 years or so, the meteoric rise of the internet, the process of trade liberalization and the globalization of the value chain have particularly transformed the SME's conditions for success in international markets. Export no longer represents, had it ever represented, the one and only internationalization strategy for the SME. Already some 15 years ago, there were estimated to be some 1 million SMEs or about $30 \%$ of the industrialized world's manufacturers that conducted business internationally (Knight \& Kim, 2009), either through export but also through licensing agreements, consortia, strategic alliances, joint ventures and Green field or brown field investments. A gulf has thus opened between the questions serving to evaluate the abilities of the SME wishing to export and the current keys for success abroad for the SME, all strategies combined.

In light of these observations drawn from the literature review, the use of the Delphi method for the second research component compelled the experts to think outside the box, laying the foundation for a new international qualification framework for SMEs. Hence, the five building blocks of the construct are described below.

\subsection{Beyond the Export Strategy}

Export is an approach (generally associated with the manufacturing sector) seeking to expand the firm's activities internationally resulting in the sale of tangible products (consumer or industrial goods) to foreign clients. But according to the Delphi method's expert panel, export diagnostic frameworks do not adequately evaluate the internationalization capacities for those SMEs in other sectors such as professional services or distribution, as the export diagnostic's evaluation criteria are essentially characterized by a "manufacturer's" reality. Moreover, the range of internationalization modalities available to SMEs in other sectors of activity is broader (Soparnot, Grandval, \& Vergnaud, 2005), including in particular: licensing, franchising, technology or know-how transfer, strategic alliances, etc.: internationalization options that require mid-to long-term agreements with foreign partners. The revisited Uppsala internationalization process (Johanson \& Vahlne, 2009) also deals with this range of modalities by insisting on the importance of the firm's business network and relationships in starting and developing its activities abroad. By easing access to critical information, the firm's networks and relationships, be they informal or professional, may help it identify international opportunities (Kontinen \& Ojala, 2011). These sources of information, especially mentors and professional forums, are said to be beneficial to SMEs and entrepreneurs in identifying valuable opportunities abroad (Ogzen \& Baron, 2007).

By evaluating the SME solely on the basis of its export capacities, several internationalization strategies that may be more appropriate could be discarded from the outset. For example, a firm that manufactures difficult to export products (e.g., bricks) would be discarded if one only heeded export related criteria. On the other hand, this firm could, as long as certain conditions are met, entertain the idea of a technology transfer (licensing agreement) abroad (David, 2007).Consequently, the international qualification framework recommended in this article takes into consideration a number of criteria reflecting new variables or variables of greater scope, in particular with regards to management in an intercultural context, intellectual property, knowledge of foreign languages, capacity to invest, access to capital or to new sources of funding (e.g., crowdfunding), etc.

\subsection{Beyond the Firm's Functional Areas}

The conventional export diagnostic framework covers each of the firm's functional areas (e.g., finance, marketing, $R \& D$, HR, management, etc.) in order to evaluate their assets and liabilities in light of the internationalization project. However, the evaluation of these functions though necessary, is insufficient in 
appraising the firm's readiness for carrying out different internationalization strategies. Consequently, the first iteration of the Delphi method not only updated, but generated all the criteria to consider in the evaluation of the SME that is going global. During the course of the second iteration, the experts devoted their attention to these criteria within six overall dimensions of internationalization: 1) the competencies of the managers assigned to the internationalization project, 2) the heritage of the SME within international markets, 3) the relationships the SME maintains abroad, 4) the offerings that the SME has earmarked for international markets, 5) the means at the disposal of the SME for carrying out its internationalization strategy and 6) the engagement of the SME's management in the internationalization project. Moreover, these dimensions include the criteria associated with the functional areas mentioned above, but they also go further by taking into account other aspects inherent in the reality the SME faces in its internationalization context. Forty or so evaluation criteria stem from the six dimensions as shown in Table 1 (for each dimension, three or four criteria examples are presented).

Table 1. Qualification dimensions and respective criteria

\begin{tabular}{|c|c|}
\hline Dimensions & Short list of international qualification criteria raised by the experts \\
\hline Competencies of Management & $\begin{array}{l}\text { - Training in international business } \\
\text { - Knowledge of foreign markets } \\
\text { - Knowledge of foreign languages } \\
\text { - Experience in international business }\end{array}$ \\
\hline Heritage & $\begin{array}{l}\text { - Prominence, recognition of the firm globally } \\
\text { - Intellectual property held in certain countries } \\
\text { - Presence in foreign markets } \\
\text { - Lessons learned from the internationalization experience }\end{array}$ \\
\hline Relationships & $\begin{array}{l}\text { - Branches, foreign subsidiaries etc. } \\
\text { - Established business relationships in certain countries } \\
\text { - Internet presence of the SME abroad }\end{array}$ \\
\hline Offerings & $\begin{array}{l}\text { - Assets (strengths), handicaps (weaknesses) related to products, services or solutions } \\
\text { pertaining to an international expansion } \\
\text { - Adaptability of the SME's products, services or solution nswith respect to new foreign } \\
\text { markets } \\
\text { - Adapted or adaptable pricing structure and financial modalities for foreign markets }\end{array}$ \\
\hline Means & $\begin{array}{l}\text { - Financial health of the SME } \\
\text { - Access to financing or new capital } \\
\text { - Available production (operational) capacity }\end{array}$ \\
\hline Engagement & $\begin{array}{l}\text { - Top management's availability to dedicate time to international activity } \\
\text { - Top management's preparedness to invest in the international venture } \\
\text { - Level of risk tolerance } \\
\text { - Motivations, objectives, targets, scenarios and economic models pertaining to the } \\
\text { internationalization project }\end{array}$ \\
\hline
\end{tabular}

By attributing a score of 5 points to each of the CHROME (acronym taking the first letter of each of the framework's six dimensions) framework's 40 criteria or terms, the SME is evaluated out of an overall score of 200 points. Beyond the overall score, it is interesting to observe, in graphical form, the average score (out of 5) for each CHROME dimension in order to appreciate the SME's strengths and handicaps pertaining to its internationalization process. Figure 1 illustrates the average score obtained by SME XYZ along each dimension in the context of its international qualification.

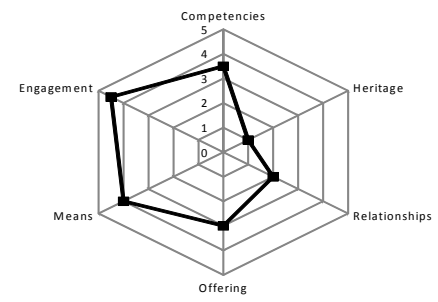

Figure 1. CHROME SME XYZ-international qualification 
This configuration is characteristic of an SME that is inexperienced globally considering its relatively weak heritage and relationships dimensions. Further, XYZ's competencies seem barely adequate for the international venture. Nevertheless, its means and engagement (having high scores) could be drawn upon to enhance its competencies and its offerings in order to better adapt these dimensions to the reality of foreign markets.

In the schematic interpretation of the CHROME results, the Delphi method experts evoke an interesting analogy to certain notions of physics. As the SME's CHROME dimensional scores (and therefore of their respective components) increase, the more one can say that it is animated by a centrifugal force, pushing it outwards (abroad). Conversely, as the scores are lower, the more the SME is animated by a centripetal force (pulling it to the centre), thus indicating it should confine itself to the domestic market.

\subsection{Beyond the "Go or No Go" Provision}

The conventional export diagnostic framework seeks essentially to determine if the firm is ready or not to export product A to country B, assuming that country B represents the most viable market. The Delphi experts contend that the SME's first step in the internationalization process should not serve to evaluate its preparedness for a predetermined market but for doing business globally without any a priori destinations. Therefore, the international qualification framework should also guide the SME towards the best options to explore in terms of countries (markets) as well as in terms of entry strategy. In light of this, the international qualification framework (CHROME) developed aims to determine to what extent the firm is predisposed for internationalization but also highlight the possible avenues in terms of market choices and access modalities to the latter. As to the evaluation of the level of SME preparedness for internationalization, the proposed framework posits that a score of 81 points (out of a total of 200) represents the threshold below which the firm should abstain from venturing abroad. Furthermore, due to the significant gap that can separate two SMEs obtaining a score at the inferior and superior limits of qualification (that is to say one obtaining a minimal score of 81 points and the other a maximal score of 200 points), a classification of qualified SMEs into four levels puts the results into perspective and provides pertinent observations and recommendations according to the respective classes: "Passe-Partout" (score between 161 and 200),"Mid-Level Pass" (score between 121 and 160), "Entry-Level Pass" (score between 81 and 120) and "Impasse" (score below 81).

\subsection{A Dual Phase Evaluation}

In consideration of the expert panel's observations, the SME's international qualification would be performed without any assumptions as to the strategic choices of entry modality or target country, rather it would serve to steer the decision-making in that regard. For example, an observed strength such as knowledge of Asian languages and markets would indicate a certain predisposition for doing business in Asia. Similarly, an observed handicap regarding financial resources would contra-indicate an investment strategy, favoring instead transactional strategies (e.g., import-export) or contractual ones (e.g., licensing, franchising or consortia).

Notwithstanding the foregoing, an aspect which the experts grappled with was the need to conduct an evaluation of the SME's preparedness in approaching a specific country or market (identified following the international qualification). The expert panel's contribution was to visualize the CHROME's application in two phases: qualification (the first), before the internationalization process and validation (the second) following the identification of the target country and the entry strategy. Similar to the international qualification, the international validation asks the same questions with respect to the SME's internationalization abilities, however this time they pertain to a country (market) and a predetermined entry strategy. It is therefore a subsequent evaluation (to the international qualification) designed to appreciate the subtleties between the capacity to conduct activities abroad in a general sense (i.e., all countries and strategies combined) and in specific areas (i.e.: in reference to a determined market and strategy). Be that as it may, the Delphi experts indicated that certain nuances must be brought to bear on certain criteria of the second phase of the evaluation. Whereas in the international qualification the internationalization risks intrinsic to the firm are examined, the international validation will weigh in on the extrinsic risks. Thus the international qualification will seek to appraise the strengths and weaknesses of the SME that is going global while the international validation will analyze the competitive advantages and disadvantages of an SME wishing to compete in a specific market (the competition then needing to be known). Consequently, the experts posit, “...the international validation cannot be performed on the heels of the international qualification as foreign market data and the strategies to employ must first be analyzed". Further, Knight and Kim (2009) highlight that the SME's ability to develop internationally is a function of the level of information it holds on the foreign target markets as well as the means at its disposal. Similar to the international qualification illustrated above, the international validation illustrated in Figure 2 
paints a different portrait of SME XYZ's abilities to do business abroad, not in absolute terms but regarding a specific country, in this case Brazil.

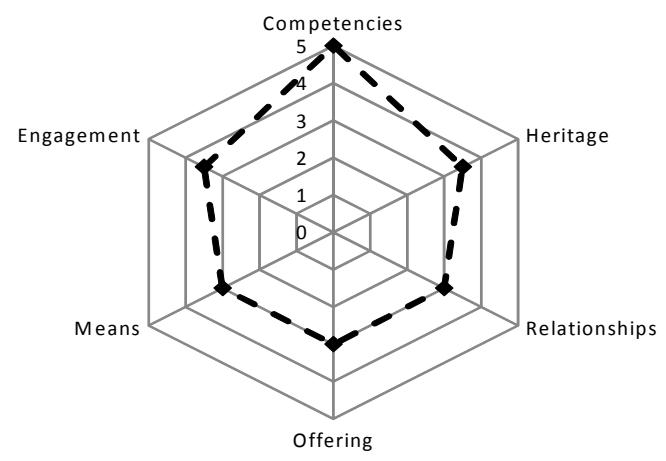

Figure 2. CHROME SME XYZ-international validation

The superimposing of the two curves (international qualification and validation) in the following figure highlights the existing gaps between SME XYZ's general preparedness for international business (international qualification) and its capacities to specifically develop the Brazilian market (international validation).

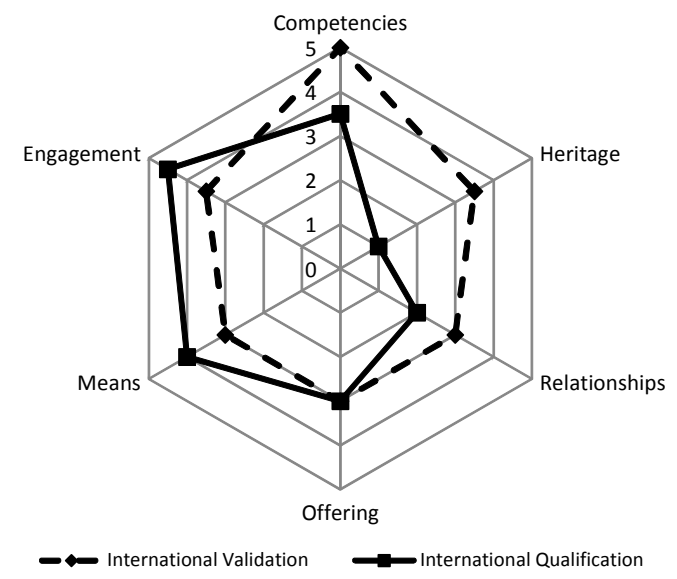

Figure 3. CHROME SME XYZ-international qualification and validation

The qualification and validation criteria remain to a greater or lesser extent the same. However, as evidenced by Figure 3, the responses to these criteria can sometimes give rise to appreciable discrepancies between the readiness to conduct international business and to do business within a specific country. When evaluating the risks the SME faces abroad, particular attention is paid to intrinsic risks (e.g., competencies, organization, experiences etc.) when performing the international qualification, whereas the international validation concerns itself more with extrinsic risks (e.g., foreign exchange, political environment, credit risk of foreign clients, respect for intellectual property etc.) to which the SME is exposed within the host country (El Fadil, 2012). The corollary is that the CHROME framework should be applied in two phases: ahead of the SME's internationalization process (international qualification) then regarding each country (market) it is considering doing business with (international validation).

\subsection{The Indispensable Role of the Consultant}

The experts who took part in the Delphi panel and therefore also in the development of the CHROME framework are unequivocal in saying "input from an external stakeholder from the public or private sector to qualify the firm is essential as he lends the comprehensiveness, perspective and objectivity needed for the exercise". However, it's not that the participation of an external expert eliminates the subjectivity associated to his experience; on the contrary, it becomes useful in the interpretation of results as such an evaluation is more an art than a mathematical exercise. The consultant's value added equally resides within his ability to question the 
assumptions of the SME's management and arrive at a most accurate assessment concerning the SME's capacities to expand abroad.

\section{Application of the CHROME Framework and Discussion}

Of the 54 firms having participated in the international qualification exercise, the overall average score measured through the CHROME lens stands at 105.8 (out of 200), corresponding to an "Entry-Level Pass". The CHROME score and class distributions of the 54 firms are illustrated in Figure 4.

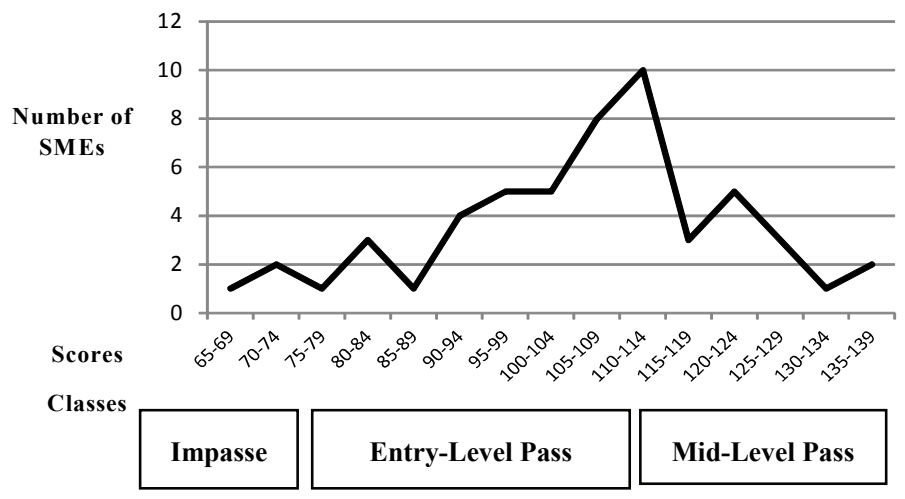

Figure 4. CHROME sample of SMEs-international qualification scores

None of the SMEs obtained the "Passe-Partout" class (score between 160 and 200) due to the fact that the group studied was rather formed of firms having expressed a need for internationalization assistance, and thus not fitting the profile of firms that would be attributed CHROME's superior class. By splitting the group of 54 firms into two sub-groups, namely one of manufacturers and the other of non-manufacturers, one notices that their respective average scores differ appreciably. The manufacturers (comprising 39 SMEs) obtain an overall average score of 103.8 whereas the non-manufacturers record an overall average score of 111.1. By examining the data more closely one finds that for each of the CHROME dimensions, the non-manufacturers record a higher score (out of 5) than the manufacturers, the only exception being the dimension of Means (see Figure 5).

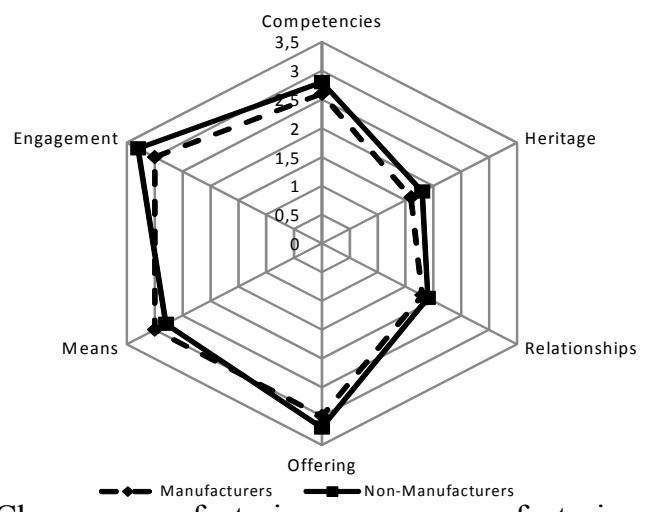

Figure 5. Chrome manufacturing vs. non-manufacturing SMEs

By examining a little more the non-manufacturers sub-group, one finds significantly higher scores among certain high-tech SMEs (e.g., software publishers, clinical research centers, etc.) who are proportionately more numerous than in the manufacturer sub-group. Indeed, these technology firms are responsible for boosting the results for the sub-group they belong to. One also finds that the innovative or technological nature of the firm would have a greater bearing than the number of employees on its preparedness for internationalization. Indeed, by splitting the 54 firms in three groups with respect to their number of employees, it is interesting to note that the sub-group with the least employees ( 25 employees or less) obtains an overall average score slightly above the second sub-group (between 26 and 100 employees), 104.6 and 104.2 respectively (the third sub-group, 
comprising SMEs with 101 employees or more, obtains an average score of 118.2). It should be emphasized that the first sub-group ( 25 employees or less) has a higher proportion of innovative or technological SMEs than the sub-group of 26 to 100 employees. Always through the CHROME lens, the relationship between revenue and overall average score, as measured by the linear correlation coefficient seems to corroborate the preceding observations.

$$
r=\operatorname{Cov}(x, y) / \sigma_{x} \sigma_{y}
$$

Indeed, with a linear correlation coefficient (r) of 0.28 for the results as a whole, the linear relationship between revenue (in \$) and CHROME score is positive but weak. Thus, revenue is not a major determinant of the SME's capacity for internationalization. The same goes for years in operation and CHROME score which has a coefficient of correlation of 0.24 , indicating a weak relationship, although positive. Further, of the five firms in operation for less than two years, four record an average score (108.4 on average) superior to the average of the entire group (105.8). These findings are characteristic of firms labeled as born global, that is, firms of a modest size, often technology oriented and operating in foreign markets from their beginnings or shortly thereafter (Oviatt \& McDougall, 1994). It turns out that these firms' handicaps, usually having to do with their heritage, relationships and means, are often compensated for by assets contained in the other CHROME dimensions, namely: competencies, offerings and engagement. Thus, based solely on revenue or years in operation, the decision to accept or reject an internationalization initiative (or to assist in its development or not) risks shelving a certain number of deserving SMEs, whereas they could capitalize on other strengths in order to succeed abroad.

\section{Conclusions: Implications and Avenues for Further Research}

The observed transformation of the conditions, practices and internationalization modalities warranted a study to revisit the approaches used to evaluate the SME's capacity for expanding globally. The framework to evaluate the SME's internationalization capacities resulting from this research, CHROME, is a departure in many respects from the conventional export diagnostic frameworks. Its application has highlighted new firm-specific assets to consider and puts into perspective the classic indicators for SME internationalization, thereby paving the way for firms that otherwise (according to traditional frameworks) would have been sidelined. According to CHROME, the firm's functional areas (HR, finance, $R \& D$, marketing, etc.) no longer represent the exclusive foundation of the evaluation, but are integrated to six new dimensions that determine the SME's readiness for internationalization. CHROME highlights the importance of performing the evaluation in two phases, firstly ahead of the internationalization process, without any assumptions regarding markets or entry strategies (international qualification) and subsequently, when the target markets are identified (international validation). This article focused essentially on the first phase of the evaluation, that is, the international qualification; therefore, it would be useful to conduct new research to examine the practical application of the international validation. Moreover, research involving a larger sample of firms would open the door to studying the suitability of attributing relative weights to each of the dimensions according to different factors such as sector of activity, firm size, or the target geographic markets. Lastly, it would be interesting to study the relationship between the SME's performance abroad and its international qualification and international validation scores, in the event that it would be possible to define beforehand appropriate base levels for this performance(revenue, return on investment, EBITDA, economies of scale generated etc.) as well as an appropriate time horizon.

\section{References}

BarNir, A., \& Smith, K. A. (2002). Inter firm alliances in the small business: The role of social networks. Journal of Small Business Management, 40, 219-232. http://dx.doi.org/10.1111/1540-627X.00052

Cavusgil, S., \& Tamerand Nason, R. W. (1990). Assessment of Company Readiness to Export. International Marketing Strategy, 129-139. Oxford: Pergamon Press.

Coviello, N. E., \& Munro, H. J. (1997). Network relationships and the internationalization process of small software firms. International Business Review, 6(4), 361-386. http://dx.doi.org/10.1016/S0969-5931(97)00010-3

David, J. P. (2007). Comment développer les marchés internationaux. Montréal: Éditions Transcontinental,Collection Entreprendre.

El, F. J. (2012). La gestion des risques de sous-traitance manufacturière en Chine. thèse dedoctorat, Université du Québec à Trois-Rivières. 
Hara, G., \& Kanai, T. (1994). Entrepreneurial networks across oceans to promote international strategic alliance forsmall businesses. Journal of Business Venturing, 9(6), 489-507. http://dx.doi.org/10.1016/0883-9026(94)90018-3

Knight, G. A., \& Kim, D. (2009). International business competence and the contemporary firm. Journal of International Business Studies, 40(9), 255-273. http://dx.doi.org/10.1057/palgrave.jibs.8400397

Johanson, J., \& Vahlne, J. (2009). The Uppsala internationalization process model revisited: From liability of foreignness to liability of outsidership. Journal of International Business Studies, 40(9), 1411-1431. http://dx.doi.org/10.1057/jibs.2009.24

Kontinen, T., \& ArtoOjala, A. (2011). International opportunity recognition among small and medium-sized family firms. Journal of Small Business Management, 49(3), 490-514. http://dx.doi.org/10.1111/j.1540-627X.2011.00326.x

Kumcu, E. (1995). Export Readiness of Smaller U.S. Exporters in Response to European Integration. Fourth Biennial International Conference, European Community Studies Association. Ball State University, Charleston, South Carolina.

Luong, L. P. (2010). Les antécédents de la performance à l'exportation des PME: un modèlehiérarchisant les déterminants, application au Vietnam. Congrès International Francophone entreprenariat et PME, Université Montesquieu Bordeaux IV.

Meier, O., \& Meschi, P. (2010). Approche intégrée ou partielle de l'internationalisation des firmes: modèles Uppsala (1997 et 2009) face à l'approche international new venture et aux théories de la firme. Management International, 15(1), 11-18. http://dx.doi.org/10.7202/045621ar

Oviatt, B., \& McDougall, P. (1994). Toward a Theory of International New Ventures.Journal of International Business Studies, 25, 45-64.http://dx.doi.org/10.1057/palgrave.jibs.8490193

Ozgen, E., \& Baron, R. A. (2007). Social sources of information in opportunity recognition: Effects of mentors,industry networks, and professional forums. Journal of Business Venturing, 22(2), 174-192. http://dx.doi.org/10.1016/j.jbusvent.2005.12.001

Soparnot, R., Grandval, S., \&Vergnaud, S. (2005). La stratégie d'internationalisation des PME: lemodèle Mercadex-Desjardins. Dans Concepts et cas en management stratégique (pp. 161-175). Hermes/Lavoisier, Paris.

Tan, A., Brewer, P., \& Liesch, P. (2010). Measuring export readiness using a multiple-item index. European International Business Academy (EIBA) conference. Portugal: Porto.

Wiedersheim, P. F., Welch, L. S., \& Olson, H. C. (1975). Before the First Export Order: A Behavioral Model. Working Paper, No. 10.

Note

Note 1. The Delphi Method aims to have the reflections of experts evolve, in an anonymous manner, toward a consensus of opinion through the use of successive questionnaires.

\section{Copyrights}

Copyright for this article is retained by the author(s), with first publication rights granted to the journal.

This is an open-access article distributed under the terms and conditions of the Creative Commons Attribution license (http://creativecommons.org/licenses/by/3.0/). 